(2)

\title{
Root coverage of a previously restored tooth. A case report with a 7-year follow-up
}

This article was published in the following Dove Press journal:

Clinical, Cosmetic and Investigational Dentistry

16 June 2009

Number of times this article has been viewed

\author{
Alexander Corsair \\ Private Practice, Rockville \\ Centre, NY, USA
}

Correspondence: Alexander Corsair 364 Merrick Road, Rockville Centre, New York, NY I I570, USA Email acorsair@verizon.net

\begin{abstract}
This case report describes the treatment of a maxillary canine that had $4 \mathrm{~mm}$ of marginal gingival recession. The exposed root had been previously restored with a composite class 5 restoration. The restoration was removed and the root planed and demineralized. The root was then covered by a subepithelial connective tissue graft harvested from the palate. The flap was coronally positioned to completely cover the graft and exposed root. The healing was photographed post-operatively at one month, six months, and seven years. Root coverage increased to $100 \%$ after seven years. The zone of attached gingiva also increased.
\end{abstract}

Keywords: coronally positioned, subepithelial, connective tissue graft, keritinized gingiva, creeping reattachment

\section{Introduction}

Sub-epithelial connective tissue grafts have been used for many years to augment edentulous ridges, increase the zone of keratinized attached gingiva, and to cover exposed roots. ${ }^{1}$ More recently, periodontists have been successful in covering exposed roots that had been previously restored or carious., ${ }^{2,3}$ Few cases have been reported in the literature illustrating the long-term success of complete root coverage of a previously restored root. ${ }^{3}$ This case report illustrates the long-term success of such a case.

\section{Technique}

Several techniques have been described in the literature to cover exposed roots. ${ }^{4,5}$ A modification of the subepithelial connective graft as described by Langer and Langer ${ }^{1}$ was used in this case report.

The technique used in this case report included local anesthesia with minimal epinephrine for the recipient site. The restoration is removed and then the preparation eliminated with burs and hand instruments. Then the root surface is demineralized with a citric acid solution. The recipient site is then prepared as described in the literature. ${ }^{1}$ The preparation involves a crevicular incision which is blended into vertical incisions in the papillary area. The vertical incisions are extended deep into the vestibule and diverged apically to maintain a broad base to the flap for better blood supply. The flap is first reflected as a full-thickness mucoperiosteal flap with care not to traumatize the soft tissue. Once the flap is reflected past the exposed root to the crest of bone then a partial thickness dissection is accomplished to separate the periostium from the flap. This periosteal separation is extended apically until the 
flap is adequately mobile so that the flap margin can be coronally displaced so that the exposed root is covered without tension.

The adjacent papillas are de-epithelialized to expose the connective tissue. This allows the coronally positioned flap to attach and it also provides blood supply to the connective tissue graft. At this point the graft is harvested from the hard palate. ${ }^{6}$

The graft site is sutured with $3-0$ silk sutures and primary closure is accomplished. The graft is then placed over the exposed root to determine if the dimensions are accurate. After the required modifications, the graft is sutured in place so that it covers the exposed root, the adjacent papilla and about $3 \mathrm{~mm}$ of bone apically. The graft is sutured to the adjacent papilla with 5-0 chromic gut sutures, T28-tapered point needle. The overlying flap is then coronally positioned to cover the graft completely. This is a modification of the original technique and has been described in the literature by many authors. The flap is sutured with CV-5 Goretex sutures with a RT-16 needle. A sling suture is used, however, before the suture is passed between the teeth, the papilla is pierced on both the mesial and distal to prevent the suture from slipping off during the healing period. The vertical incisions over the recipient site are sutured with $5-0$ plain gut. Both the donor and recipient sites are covered with periodontal dressing after hemostasis has been confirmed.

Patients are instructed not to eat on or brush the graft recipient site for six weeks. Sutures are removed from the palatal donor site after seven days. The sutures in the recipient site are removed after 14 days. Chlorhexidine gluconate $0.12 \%$ mouth rinse is prescribed. The patient is seen periodically to remove stain from the teeth.

\section{Case report}

The following case illustrates root coverage on tooth \#11 where a composite class $\mathrm{V}$ restoration was present. The photographs illustrate the procedure as described above and include one-month, six-month, and seven-year postoperative photos. Four $\mathrm{mm}$ of recession was present and only one $\mathrm{mm}$ of attached keratinized gingiva was present (Figure 1). The author explained the procedure and the risks and alternatives. The patient chose to have the restoration removed and root coverage attempted.

The restoration was removed as described above (Figure 2). The recipient site was prepared and the connective graft sutured to the papilla as described. Figure 3 illustrates a graft sutured in place from a different but similar case. The flap

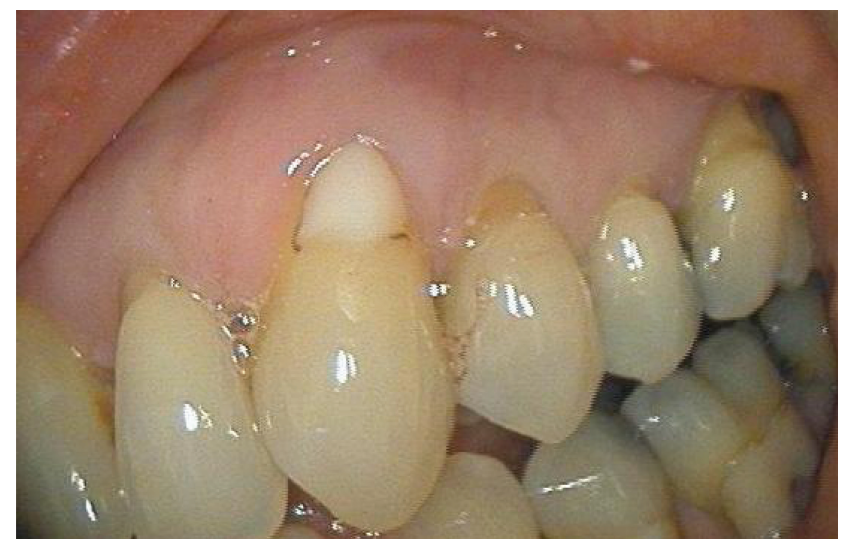

Figure I Pre-op tooth \#II.

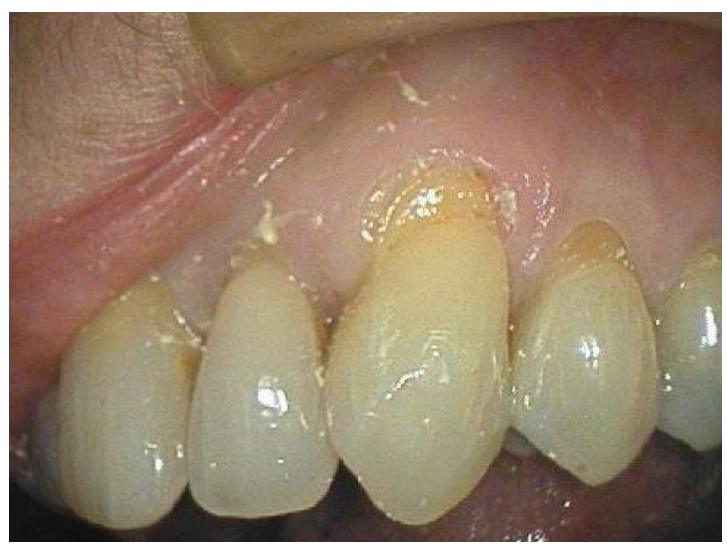

Figure 2 Restoration removed.

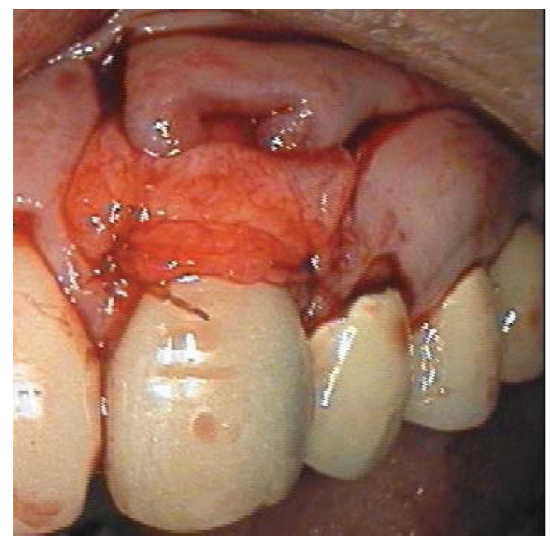

Figure 3 Graft sutured: a different case. 
was then coronally displaced and sutured to cover the graft completely as described above (Figure 4). The connective tissue graft was harvested from the palate and then the palatal donor site sutured to control bleeding and facilitate healing (Figure 5).

A one-month post-op is illustrated in Figure 6. Almost $100 \%$ root coverage was obtained. The extent and thickness of the attached keritinized gingiva was increased significantly. However at this time-point there is some root exposure and the gingiva is too thick and the surface is not smooth. Over the next five months, the gingiva matured and blended in more with the adjacent tissues. Root coverage is less than $100 \%$ (six-month post-op; Figure 7).

Figure 8 shows the seven-year post-op root and illustrates complete root coverage and a restoration of attached gingiva and good esthetics.

There appears to be new root coverage on the facial of tooth \#10 as well as a result of "creeping reattachment".

\section{Discussion}

The success rate of root coverage reported in the literature by Goldstein ${ }^{2}$ was $97 \%$ for intact roots and $92 \%$ for carious roots over a 34-month follow up. In his study, 18 of the 27 roots treated had $100 \%$ root coverage. Short- and long-term results of root coverage with connective tissue grafts on intact roots tended to improve with time as reported in the literature by Lee and colleagues. ${ }^{7}$

In their study, root coverage improved from $85 \%$ at three months to $91 \%$ at six months and finally $92 \%$ at 12 months. Adverse postoperative events are usually swelling, moderate pain, and rarely hematoma or post operative bleeding. ${ }^{8}$

The surgery in this case report was done in June, 2000. Many new techniques have been developed and tested since that time. However a good long-term result was obtained

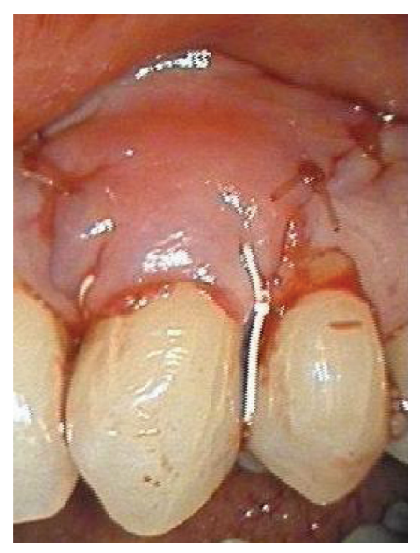

Figure 4 Coronally positioned flap.

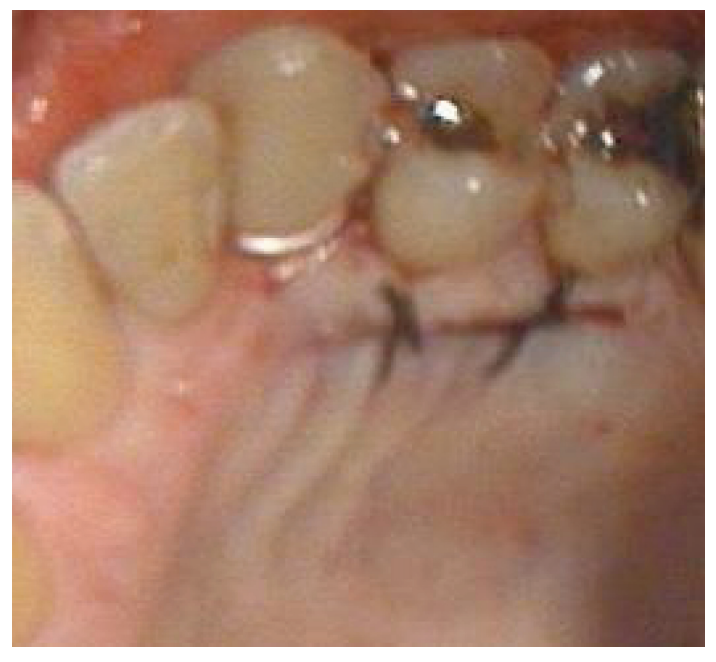

Figure 5 Donor site sutured.

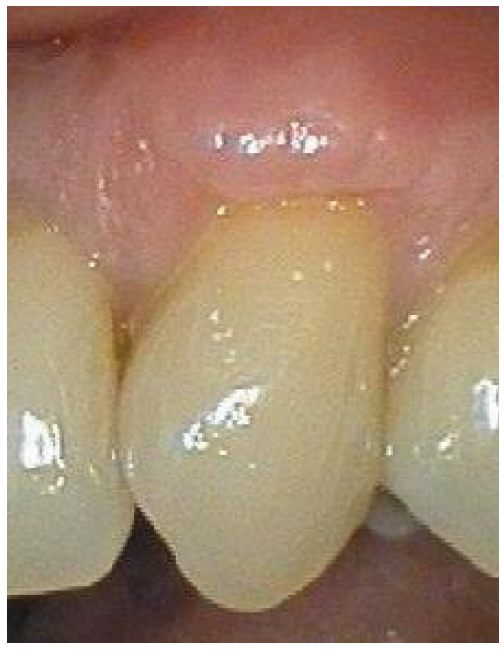

Figure 6 One month post-op.

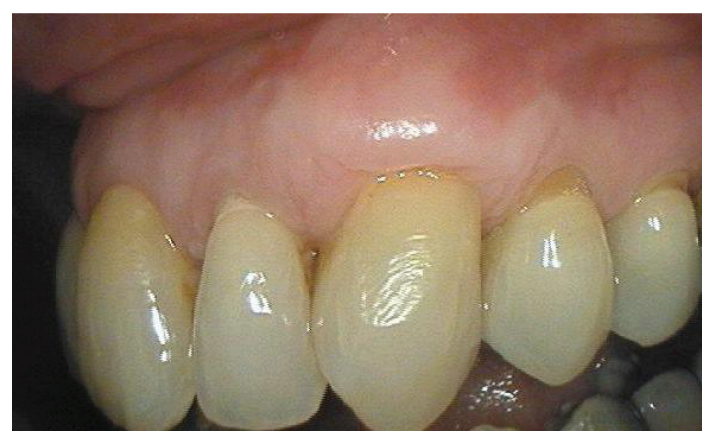

Figure 7 Six months post-op. 


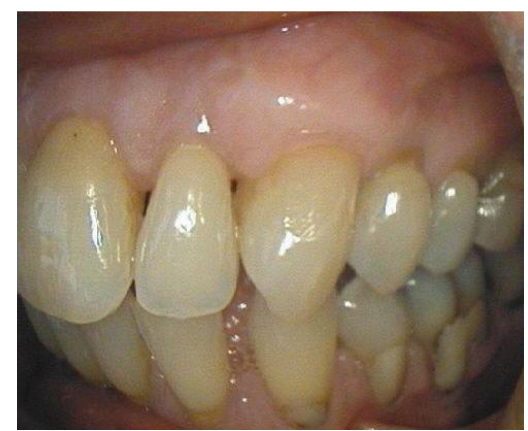

Figure 8 Seven years post-op.

with the original subepithelial connective tissue graft and coronally advanced flap. Not only was the previously restored root completely covered but the zone of attached gingiva was increased. No scar tissue is seen and the new gingiva blends in very well with the surrounding tissue. The seven-year post-op photo (Figure 8) shows more root coverage than the one-month and six-month postoperative photos. This illustrates "creeping re attachment" which is also seen for tooth \#10.

Connective tissue grafts have been used to cover resin ionomers in localized gingival recessions. ${ }^{9}$ Are the new techniques more effective short- and long-term? Are they less invasive? Is it necessary to remove existing restorations? Studies will be required to answer these questions.

\section{Conclusion}

The subepithelial connective tissue graft can be used to cover previously restored roots. This case report illustrates complete root coverage of a previously restored root.
The report illustrates a seven-year follow-up showing maintenance of complete root coverage and improvement of the result functionally and esthetically over this time period. The phenomenon of "creeping reattachment" is demonstrated.

This technique provides the dentist and the patient with an opportunity to replace unesthetic restorations and achieve a better esthetic and functional result.

\section{Disclosure}

The author reports no conflicts of interest in this work.

\section{References}

1. Langer B, Langer L. Subepithelial connective tissue graft technique for root coverage. J Periodontol. 1985;56:715-720.

2. Goldstein M, Nasatzky E, Goultschin J, Boyan BD, Schwartz Z. Coverage of previously carious roots is as predictable a procedure as coverage of intact roots. J Periodontol. 2002;73:1419-1426.

3. Oates TW, Robinson M, Gunsolley JC. Surgical therapies for the treatment of gingival recession. A systematic review. Ann Periodontol. 2002;8:12-37.

4. Matter J. Free gingival graft and coronally repositioned flap. A 2-year follow-up report. J Clin Periodontol. 1979;6:437-442.

5. Harris RK. A comparison of two techniques for obtaining a connective tissue graft from the palate. Int J Periodontics Restorative Dent. 1997; 17:260-271

6. Harris RJ. Root coverage with connective tissue grafts: an evaluation of short- and long-term results. J Periodontol. 2006;9:1054-1059.

7. Lee YM, Kim JY, Ku Y, Rhyu IN, Han SB, Choi CP. A 3-year longitudinal evaluation of subpedicle connective tissue grafts for gingival recession coverage. J Periodontol. 2002;73:1412-1418.

8. Griffin TJ, Cheung WS, Zavras AI, Damoulis PD. Postoperative complications following gingival augmentation procedures. J Periodontol. 2006;77:2070-2079.

9. Alkan A, Keskiner I, Yuzbasioglu E. Connective tissue grafting on resin ionomer in localized gingival recession. J Periodontol. 2006;77:1446-1451.
Clinical, Cosmetic and Investigational Dentistry

\section{Publish your work in this journal}

Clinical, Cosmetic and Investigational Dentistry is an international, peer-reviewed, open access, online journal focusing on the latest clinical and experimental research in dentistry with specific emphasis on cosmetic interventions. Innovative developments in dental materials, techniques and devices that improve outcomes

\section{Dovepress}

and patient satisfaction and preference will be highlighted. The manuscript management system is completely online and includes a very quick and fair peer-review system, which is all easy to use. Visit http://www.dovepress.com/testimonials.php to read real quotes from published authors. 